\title{
A Note on Texts and References
}

When this manuscript was being readied for the press, three volumes of the Kent State "Bicentennial Edition" of The Novels and Related Works of Charles Brockden Brown were available. As reference texts for this study I have used Wieland; or, The Transformation: An American Tale (1798), Arthur Mervyn; or, Memoirs of the Year 1793 (1799-1800), and corrected page proofs of Ormond; or, The Secret Witness (1799-Kent, Ohio: Kent State University Press, 1977, 1980, 1982. For Edgar Huntly; or, Memoirs of a Sleep-Walker (1799), Clara Howard; or, The Enthusiasm of Love (1801), and Jane Talbot (1801) I used the David McKay editions (Philadelphia: 1887).

Brown edited three periodicals during his career: The Montbly Magazine and American Review (New York: Vols. 1-3, 1799-1800), The Literary Magazine and American Register (Philadelphia: Vols. 1-8, 1803-1808), and The American Register, or General Repository of History, Politics, and Science (Philadelphia: 1807-1811; Brown edited vols. 1-5). Footnote reference to these periodicals is by short title (American Register, etc.).

The following sources, to which I make frequent reference, are cited parenthetically in my text rather than in numbered notes:

Allen, Paul. The Life of Charles Brockden Brown. Facsimile of a printer's proof (ca. 1814). Delmar, N.Y.: Scholars' Facsimiles and Reprints, 1975. (Allen)

Bennett, Charles E. “The Charles Brockden Brown Canon." Ph.D. diss., University of North Carolina, 1974. (Bennett)

Clark, David Lee. Charles Brockden Brown: Pioneer Voice of America. Durham: Duke University Press, 1952. (Clark)

Dunlap, William. Diary. New York: Benjamin Blom, 1969. (Dunlap,

Diary) delphia: James P. Parke, 1815. (Dunlap, Life)

Poe, Edgar Allan. The Complete Works. Edited by James A. Harrison (1902). New York: AMS Press, 1965. (Poe) 
Smith, Elihu Hubbard. Diary. Edited by James E. Cronin. Philadelphia: American Philosophical Society, 1973. (Smith)

Warfel, Harry R. Charles Brockden Brown: American Gothic Novelist. Gainesville: University of Florida Press, 1949. (Warfel) 